\title{
Supply Chain Analytics Maturity Model: Sebuah Tinjauan Pustaka
}

\author{
Mayshel Yolanda Sitorus, Imam Baihaqi, dan Dewie Saktia Ardiantono \\ Departemen Manajemen Bisnis, Institut Teknologi Sepuluh Nopember (ITS) \\ e-mail: imam_b@na.its.ac.id
}

\begin{abstract}
Abstrak-Supply chain saat ini telah menjadi lebih kompleks, lebih luas, serta lebih melibatkan banyak pihak setiap harinya. Peningkatan jumlah data yang signifikan dari suatu rantai pasok menyebabkan perusahaan kesulitan untuk melaksanakan rutinitasnya dengan tetap mempertahankan bahkan meningkatkan keunggulan kompetitif mereka. Munculnya business analytics dalam supply chain atau dikenal dengan supply chain analytics (SCA) ditujukan untuk memudahkan perusahaan dalam mengumpulkan, mengolah, serta menginterpretasikan data sehingga perusahaan mendapat wawasan tentang operasi bisnis serta membuat keputusan berbasis fakta yang lebih baik pada rantai pasok mereka. Oleh karena itu, perusahaan perlu mengetahui kondisi tingkat kematangan (maturity level) dalam menerapkan SCA saat ini untuk dapat mengembangkan penerapan SCA ke tingkat yang lebih tinggi. Saat ini, masih belum banyak literatur yang meneliti lebih lanjut mengenai framework untuk mengukur penerapan SCA pada suatu perusahaan. Mengingat pentingnya pengukuran penerapan SCA, maka paper ini akan melakukan sebuah kajian pustaka terkait beberapa penelitian terdahulu tentang framework pengukuran tingkat kematangan penerapan SCA (SCA maturity model) pada perusahaan.
\end{abstract}

Kata Kunci-Business Analytics, Literature Review, SCA Maturity Model, Supply Chain Analytics, Supply Chain Management.

\section{PENDAHULUAN}

$\mathrm{S}_{\mathrm{n}}^{\mathrm{n}}$ EIRING dengan meningkatnya iklim kompetitif bisnis, menciptakan sebuah keunggulan kompetitif menjadi kunci utama untuk mencapai kesuksesan [1]. Alih-alih memaksimalkan keuntungan sebuah perusahaan, supply chain management menunjukkan bahwa sebuah perusahaan seharusnya bertujuan untuk memaksimalkan keuntungan keseluruhan aliran supply chain [2]. Oleh karena itu, kompetisi seharusnya diantara supply chain bukan antarperusahaan. Semakin baik kinerja supply chain sebuah perusahaan, maka pertumbuhan pendapatan perusahaan juga semakin meningkat. Hal ini dibuktikan oleh penelitian yang dilakukan oleh Accenture (2014), dimana 79\% perusahaan dengan kinerja supply chain yang tinggi akan mengalami pertumbuhan pendapatan yang lebih tinggi dari rata-rata perusahaan lainnya dalam industri yang sama [5].

Saat ini, penggunaan big data analytics menarik banyak perhatian di seluruh dunia. Secara khusus, big data analytics ini telah memunculkan rantai pasokan yang cerdas yang dapat membantu meningkatkan manajemen rantai pasokan dengan berbagai cara (4)[3]. Bagi perusahaan, memanfatkan keuntungan pengetahuan yang dapat diambil dari big data menjadi dasar untuk bersaing dalam pasar. Mayoritas dari pemain bisnis pada saat ini yang menggunakan big data sebagai paradigma baru seperti menawarkan janji yang tidak berkesudahan akan transformasi bisnis dan juga peningkatan efisiensi operasional bisnisnya. Jika dilihat dalam SCM di era modern, masalah penting yang tengah dihadapi adalah bagaimana suatu organisasi dapat merumuskan strategi yang efektif dan futuristic secara tepat waktu dan akurat. Data analitik tidak hanya digunakan untuk merekam aktivitas pelanggan di masa lalu, namun juga untuk memprediksi perilaku pelangan di masa depan. Analisis data berdasarkan teknik statistik atau komputer dalam bisnis ini dikenal dengan istilah Business Analytics (BA). Dengan memanfaatkan BA, perusahaan dapat bekerja dengan lead time yang optimal dan meningkatkan tingkat akurat dalam memprediksi masa depan guna mengatasi ketidakpastian. Pemanfaatan BA dalam SCM dikenal dengan istilah supply chain analytics (SCA).

Beberapa perusahaan telah lama mengandalkan SCA untuk meningkatkan kapabilitas memproses sebuah informasi [4]. Selain itu, SCA juga sedang dimanfaatkan untuk memfasilitasi transparansi dan meningkatkan keberlanjutan rantai pasokan. SCA mengacu pada penggunaan alat-alat analitik dan berbagai aplikasi untuk melaporkan pengambilan keputusan, dimana pada akhirnya SCA meningkatkan level kinerja rantai pasokan. SCA juga dapat mensinkronisasi SCM dengan menggerakkan aliran informasi yang terpisah yang memungkinkan organisasi untuk menangkap, memproses, menganalisis, menyimpan serta bertukar data operasional mereka [5] sehingga akan berpotensi dalam meningkatkan efisiensi dan efektifitas dalam kegiatan operasionalnya.

Saat ini, masih belum banyak literatur yang membahas lebih lanjut mengenai framework untuk mengukur penerapan SCA pada suatu perusahaan. Hal ini dibuktikan dengan penelitian yang dilakukan oleh Buyukozkan (2019) yang mengemukakan bahwa sebagian besar peneliti hanya membahas terkait dengan komponen-komponen SCA dan hanya sedikit yang membahas terkait dengan pengukuran kematangan SCA [6]. Salah satu model yang cukup terkenal dalam pengukuran kematangan SCA adalah model yang dirumuskan oleh Gartner [7]. Tohamy menyatakan bahwa SCA maturity model milik Gartner terdiri atas lima tingkat (levels) dengan menggunakan tujuh dimensi yaitu goal, data, talent, organizational model, use cases, analytics techniques, serta supporting technologies [7].

Kekurangan dari model Gartner ini, dimensi yang mereka rumuskan belum melihat dari sisi aktivitas yang terdapat dalam suatu aliran rantai pasok secara detail. Melihat pentingnya pengukuran penerapan SCA dalam suatu 
Tabel 1.

Tahapan dalam Melakukan Proses Tinjauan Pustaka

\begin{tabular}{lll}
\hline \hline \multicolumn{2}{c}{ Langkah-Langkah } & \multicolumn{1}{c}{ Tahapan } \\
\hline 1 & Latar belakang melakukan tinjauan & Perencanaan \\
2 & Menetapkan pertanyaan penelitian & \\
3 & Mencari literatur & \\
4 & Menyeleksi penelitian yang ada & Pengelolaan \\
5 & Mengutip data & \\
6 & Menganalisis data & Analisis Hasil \\
7 & Menyajikan hasil tinjauan pustaka & Tinjauan dan \\
8 & Menarik kesimpulan & Kesimpulan \\
\hline \hline
\end{tabular}

Tabel 2.

Tujuan Tipe Analytics dan Metode yang Digunakan

\begin{tabular}{|c|c|c|}
\hline $\begin{array}{c}\text { Tipe } \\
\text { Analytics }\end{array}$ & Tujuan & $\begin{array}{c}\text { Contoh Metode } \\
\text { yang Digunakan }\end{array}$ \\
\hline Descriptive & $\begin{array}{l}\text { Mengidentifikasi } \\
\text { kemungkinan tren secara } \\
\text { luas pada set data atau } \\
\text { database. Bertujuan } \\
\text { mendapatkan gambaran } \\
\text { kasar tentang apa yang } \\
\text { umumnya data terlihat } \\
\text { seperti dan kriteria apa yang } \\
\text { mungkin memiliki potensi } \\
\text { mengidentifikasi tren atau } \\
\text { bisnis masa depan }\end{array}$ & $\begin{array}{l}\text { Descriptive } \\
\text { statistics, ukuran } \\
\text { disperse (standar } \\
\text { deviasi), grafik, } \\
\text { sorting methods, } \\
\text { frequency } \\
\text { distributions, } \\
\text { probability } \\
\text { distribution, dan } \\
\text { sampling methods. }\end{array}$ \\
\hline Predictive & $\begin{array}{l}\text { Membangun model prediksi } \\
\text { yang dirsncang untuk } \\
\text { mengidentifikasi dan } \\
\text { memprediksi tren masa } \\
\text { depan }\end{array}$ & $\begin{array}{l}\text { Metode statistik } \\
\text { seperti multiple } \\
\text { regression dan } \\
\text { ANOVA, metode } \\
\text { sistem informasi } \\
\text { seperti data mining } \\
\text { and sorting, dan } \\
\text { metode penelitian } \\
\text { operasional seperti } \\
\text { model peramalan } \\
\text { (forecasting } \\
\text { model). }\end{array}$ \\
\hline Prescriptive & $\begin{array}{l}\text { Mengalokasikan sumber } \\
\text { daya secara optimal untuk } \\
\text { memanfaatkan tren yang } \\
\text { diprediksi atau peluang yang } \\
\text { ada di masa depan }\end{array}$ & $\begin{array}{l}\text { Metodologi } \\
\text { penelitian } \\
\text { operasional seperti } \\
\text { linear } \\
\text { programming and } \\
\text { decision theory } \\
\end{array}$ \\
\hline
\end{tabular}

perusahaan ini, maka paper ini mengadopsi pendekatan literature review dengan tujuan untuk mengetahui dimensi SCA yang akan digunakan dalam pengukuran penerapan supply chain analytics maturity model pada suatu perusahaan. Oleh karena itu, untuk memenuhi tujuan penelitian, maka pertanyaan penelitian yang dirumuskan adalah "Aspek apa saja yang perlu diperhatikan dalam mengukur penerapan SCA pada suatu perusahaan?". Dalam paper ini akan diawali dengan menjelaskan definisi dari supply chain management dan supply chain operations reference (SCOR), kemudian dilanjutkan dengan membahas terkait dengan business analytics, supply chain analytics dan SCA maturity framework. Terakhir, yaitu menjelaskan beberapa referensi supply chain maturity model.

\section{METODE PENELITIAN}

Metode penelitian ini adalah sebuah tinjauan sistematis terhadap berbagai macam literatur terkait dengan big data analytics, supply chain analytics, dan juga beberapa

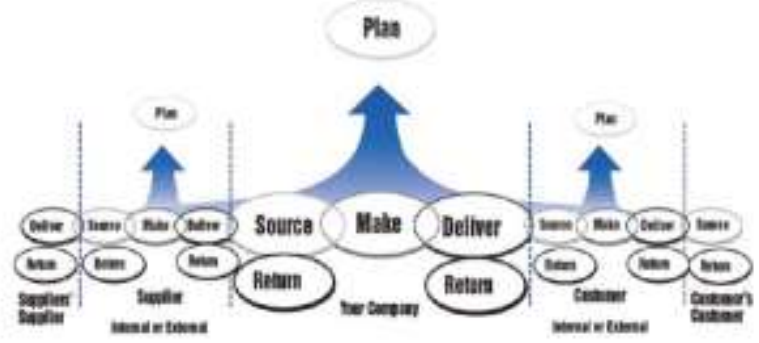

Gambar 1. Model SCOR

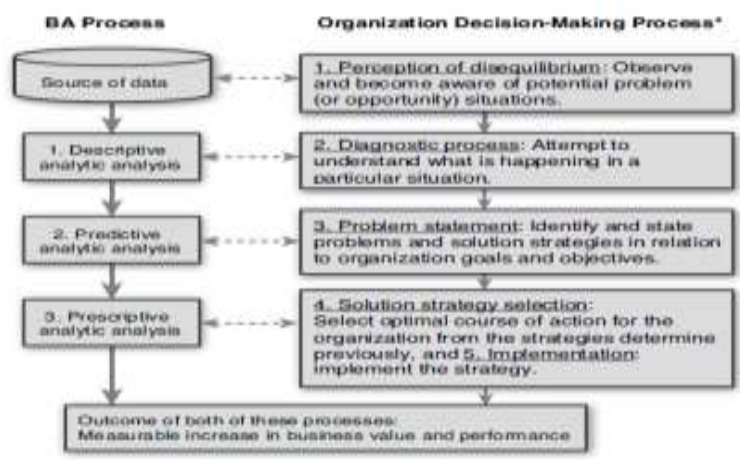

Gambar 2. Hubungan antara Proses BA dengan Proses Pengambilan Keputusan dalam Organisasi
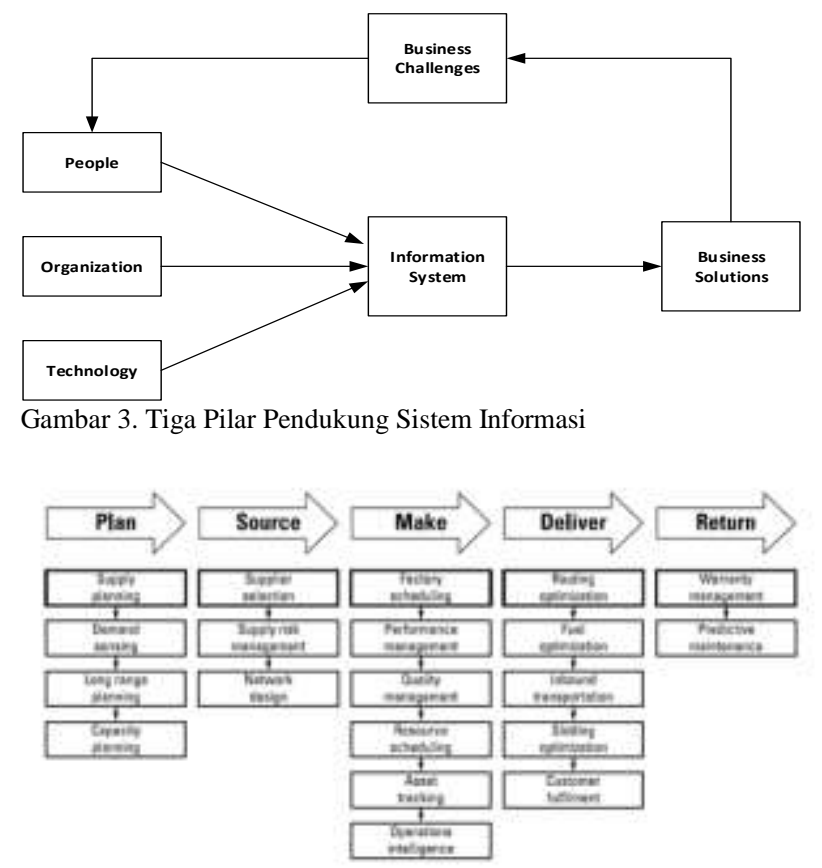

Gambar 4. Aktivitas Supply Chain Analytics pada Model SCOR

referensi maturity model[8], [9]. Tinjauan sistematis ini mengadopsi sebuah proses yang sebelumnya telah direncanakan yang bertujuan untuk meminimalisir bias melalui pencarian penelitian yang relevan dan dengan menggunakan kriteria yang jelas dalam proses meninjau dan menyeleksi literatur [10]. Proses tinjauan pustaka ditampilkan pada Tabel 1.

Langkah awal dalam melakukan tinjauan pustaka ini adalah mengetahui terlebih dahulu latar belakang melakukan tinjauan kemudian menetapkan pertanyaan penelitian. Selanjutnya, pada tahap pencarian literatur peniliti memfokuskan pencarian pada literatur akademik dan juga laporan yang diterbitkan beberapa perusahaan konsultan 

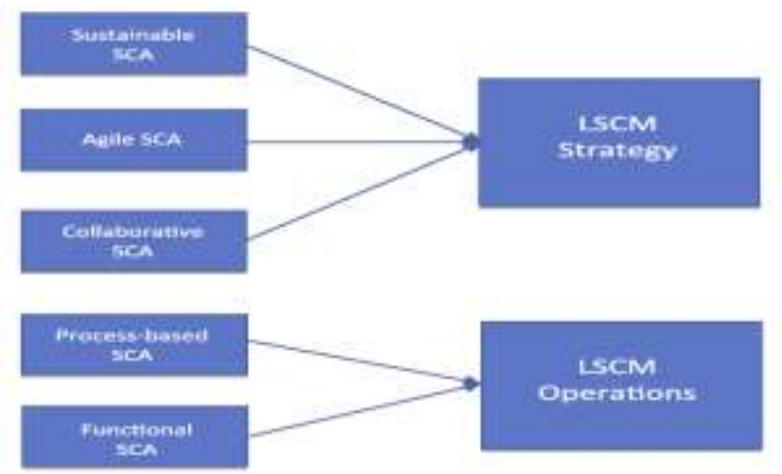

Gambar 5. SCA Maturity Model

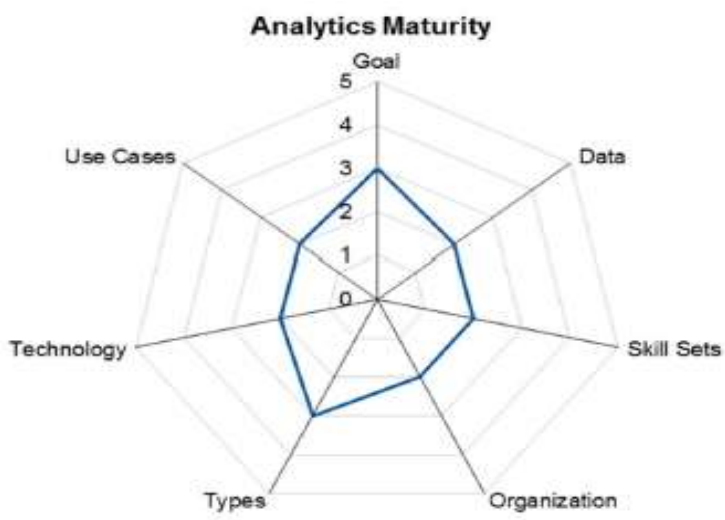

Gambar 6. Supply Chain Analytics Maturity Level Across Seven Dimensions

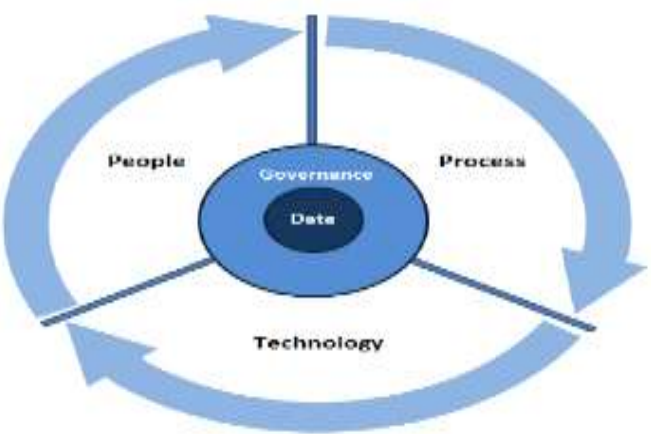

Gambar 7. GoA Enterprise Data Capabilities Framework

seperti Accenture, PRTM Management, dan sebagainya. Setelah memperoleh literatur, selanjutnya penulis menyeleksi literatur tersebut, mengutip data, menyajikan hasil tinjauan pustaka, dan kemudian menarik kesimpulan berdasarkan hasil tinjauan pustaka. Pada proses ini, penulis menemukan total 40 paper yang membahas terkait dengan supply chain analytucs. Namun, hanya 27 paper yang secara spesifik membahas mengenai supply chain analytics maturity model.

\section{ANALISIS DAN DISKUSI}

\section{A. Supply Chain Management}

Manajemen rantai pasok merupakan sebuah pendekatan dalam merancang, mengelola, dan melaksanakan semua kegiatan mulai dari perencanaan hingga pendistribusian pada seluruh elemen rantai pasok, termasuk jaringan pemasok, manufaktur, dan juga distributor [11]. Manajemen rantai pasok juga dapat didefinisikan sebagai sebuah koordinasi
Tabel 3.

Dimensi BDA capabilities maturity

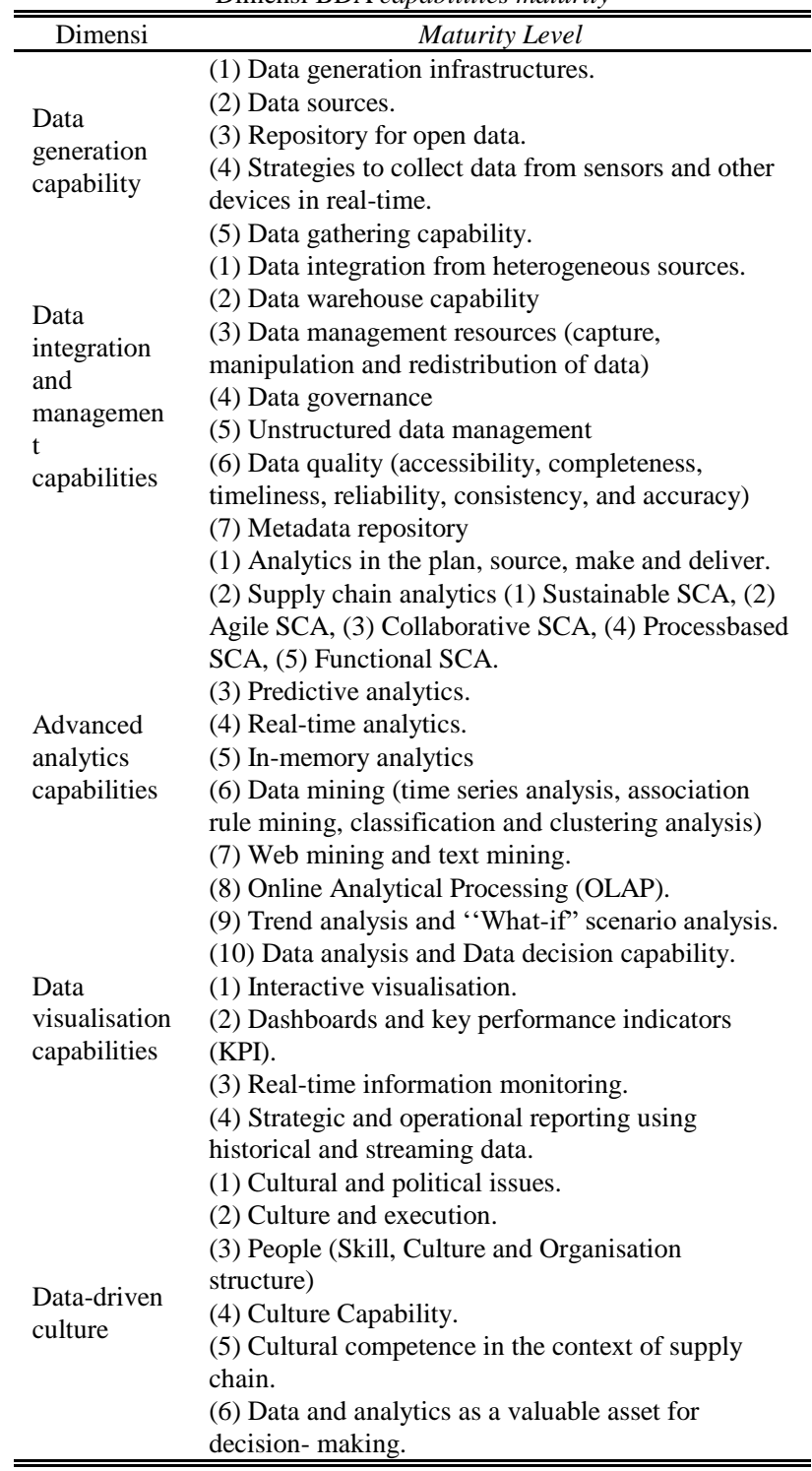

yang strategis dan sistematis pada fungsi bisnis secara tradisional dan juga sebagai taktik di seluruh fungsi bisnis dalam perusahaan tertentu maupun dalam seluruh rantai pasokan dengan tujuan untuk meningkatkan kinerja jangka panjang baik dari perusahaan masing-masing maupun rantai pasokan secara keseluruhan [12]. Berdasarkan definisi manajemen rantai pasok yang telah dijelaskan sebelumnya, maka dapat dikatakan bahwa rantai pasok adalah jaringan fisiknya, sedangkan manajemen rantai pasok adalah metode, alat, atau metode pengelolaannya. Sehingga, manajemen rantai pasok ini tidak hanya berorientasi pada urusan internal sebuah perusahaan, melainkan juga urusan eksternal yang menyangkut hubungan dengan perusahaan-perusahaan mitra yang lainnya. Tujuan utama dari manajemen rantai pasok adalah untuk memaksimalkan laba yang didapatkan (supply chain surplus) dengan meningkatkan pendapatan dan meminimalkan biaya rantai pasok.

\section{B. Supply Chain Operations Reference (SCOR)}

Salah satu tools yang dapat mengukur kinerja rantai pasok ini adalah dengan menggunakan model SCOR. Model SCOR ini menyajikan deskripsi terkait dengan proses rantai pasok, 
kemudian dapat juga menjadi sebuah framework untuk menghubungkan antara proses-proses dalam rantai pasok, selain itu juga menyajikan satu set metriks untuk mengukur kinerja rantai pasok [13]. Berdasarkan Supply Chain Council (2009) dalam Li et al (2011), model SCOR terdiri atas lima komponen (Gambar 1). Kelima komponen model SCOR yang digunakan untuk mengukur kinerja rantai pasok diantaranya yaitu ; (1)Plan, merupakan proses yang mencakup perencanaan kebutuhan pengadaan, produksi, distribusi, dan pengembalian barang; (2) Source, merupakan proses pengadaan barang maupun jasa untuk memenuhi permintaan pelanggan; (3)Make, merupakan proses melakukan transformasi bahan baku menjadi produk yang diinginkan; (4)Deliver, merupakan proses pengiriman barang untuk memenuhi permintaan barang atau jasa; (5)Return, merupakan proses mengembalikan atau menerima pengembalian produk yang disebabkan oleh berbagai hal.

\section{Business Analytics}

Business Analytics (BA) mengacu pada penggunaan data yang luas, analisis statistik dan kuantitatif, model explanatory dan juga model predictive, serta manajemen berbasis fakta untuk mendorong keputusan dan tindakan [14]. Terdapat beberapa tipe dari analytics, dan ada juga kebutuhan untuk mengatur tipe ini serta memahami kegunaannya [15]. Tujuan Tipe Analytics dan Metode yang digunakan dapat dilihat pada Tabel 2.Tipe analytics yang dimaksud adalah sebagai berikut: (1) Descriptive analytics, merupakan proses dana analitik untuk memberikan gambaran umum pada supply chain dari data yang sudah dikumpulkan baik secara internal maupun eksternal; (2)Predictive analytics, dimana analitik ini mencakup berbagai teknik statistik, pembelajaran data mining untuk membantu perusahaan untuk memahami output apa yang akan dihasilkan di masa yang akan datang dan bagaimana cara mengatasinya; (3)Prescriptive analytics, dimana analitik ini memberikan hasil prediksi tentang sesuatu yang akan datang sehingga dapat membantu perusahaan memecahkan suatu masalah dan mengolaborasikannya dengan nilai perusahaan. Proses BA dapat memecahkan masalah dan juga mengidentifikasi peluang untuk meningkatkan kinerja bisnis. Umumnya, memecahkan masalah dan mengidentifikasi peluang strategis untuk diikuti adalah tugas pengambilan keputusan organisasi. Namun saat ini, penggunaan BA dapat dijadikan sebagai pengambilan keputusan karena mereka memiliki proses yang sama dengan pengambilan keputusan secara manual (Gambar 2).

\section{Supply Chain Analytics}

Supply chain analytics (SCA) merupakan sebuah dasar untuk menerapkan teknologi seperti artificial intelligence (AI) ke dalam proses supply chain. Analytics ini menggambarkan kemampuan untuk membuat keputusan berdasarkan data atau dikenal dengan istilah data-driven decisions, berdasarkan ringkasan data yang relevan dan terpercaya, dan sering digambarkan dengan visualisasi seperti grafik, bagan, dan lain sebagainya. Oleh karena itu, supply chain analytics ini juga membantu untuk mengartikan semua data serta membuka pola dan mengumpulkan wawasan yang lebih dalam lagi dalam mengelola supply chain. SCA ini mencerminkan minat yang luas dalam meningkatkan nilai bisnis dari supply chain serta memanfaatkan kekuatan dari beragam teknologi dan metode analitik [4]. Selain itu, SCA juga dapat meningkatkan integrasi serta transparansi dalam supply chain[16] .

Namun untuk memiliki ketiga komponen SCA tersebut, Laudon et all (2009) menyatakan bahwa sebuah sistem informasi didukung oleh tiga pilar, yaitu people, organization, dan technology (Gambar 3)[17] . People atau sumber daya manusia yang dimiliki suatu perusahaan berperan sebagai pembuat (creator) dan pengguna sistem informasi tersebut. Selanjutnya, organization melihat lingkungan organisasi, budaya organisasi dan struktur organisasi yang seperti apa yang dapat mendukung keberlangsungan sistem informasi. Kemudian, teknologi seperti apa yang harus diterapkan untuk dapat mendukung sistem informasi tersebut. Supply chain analytics menyajikan dua tujuan utama yaitu pertama, memungkinkan bisnis untuk mengidentifikasi, mendiagnosis, dan memperbaiki ketidakefisienan dan pemborosan dalam rantai pasokannya. Kedua, SCA memungkinkan bisnis untuk menggunakan data rantai pasokan untuk mengidentifikasi, memprioritaskan, dan mengatasi peluang bisnis. Model referensi seperti SCOR dapat membantu perusahaan mengimplementasi analytics ke beberapa bagian dalam proses supply chain yang digambarkan pada Gambar 4. Trkman et al (2010) menyatakan bahwa model SCOR dapat mencerminkan fakta bahwa SCA mencakup kegiatan planning, sourcing, making, dan delivery karena model SCOR menyediakan kerangka kerja, terminologi standar, serta metriks yang dapat digunakan untuk mengevaluasi, memposisikan, dan menerapkan proses supply chain. Trkman (2010) memaparkan bahwa kegunaan analitik dalam beberapa area dalam model SCOR mencakup antara lain: (1) Analytics in Plan, dimana pada area ini menganalisis data untuk memprediksi tren pasar untuk produk dan jasa; (2) Analytics in Source, dimana pada area ini menggunakan sistem agent-based procurement dengan model procurement, pencarian, negosiasi, dan evaluasi agen untuk meningkatkan proses seleksi supplier, negosiasi harga dan evaluasi supplier; (3)Analytics in Make, dimana pada area ini merupakan proses produksi yang benar dari setiap item persediaan tidak hanya dilihat dari segi waktu, tetapi juga tentang masing-masing production belt and batch; (4)Analytics in Deliver, dimana pada area ini berbagai aplikasi BA dalam manajemen logistik teah dibuat untuk membawa produk ke pasar menjadi lebih efisien. Namun, karena keputusan pengiriman biasanya berada di akhir siklus keputusan dan beberapa perusahaan telah melakukan outsouring proses pengiriman mereka, maka dampak BA dalam pengiriman (deliver) mungkin terbatas.

\section{E. Supply Chain Analyctics Maturity Framework}

SCA secara strategis merupakan salah satu hal yang penting bagi kegiatan operasional suatu perusahaan. Menurut Wang et all (2016), SCA maturity framework dikembangkan dari berbagai dasar tujuan supply chain yang berbeda-beda, termasuk dari berbagai tingkatan seperti functional SCA, process-based SCA, collaborative SCA, agile SCA, dan sustainable SCA [18]. SCA maturity 
framework digambarkan pada Gambar 4. Sebagian besar model dan maturity frameworks dalam bidang SCM ini bertujuan untuk menganalisis dan menjelaskan proses-proses yang mana di dalam supply chain yang dapat meningkatkan tingkat efektivitas keseluruhan supply chain [19]. Namun, maturity framework yang diusulkan oleh Wang et al tidak hanya berfokus pada tingkat efektivitas supply chain saja, tetapi juga memperluas model dan maturity frameworks pada Logistik dan Supply Chain Management (LSCM).

Disisi lain, Gartner (2017) menyatakan bahwa SCA maturity model ini mendukung usaha para pemimpin dari supply chain untuk membangun kompetensi strategi analitik yang lebih kuat dari sebelumnya. Agar pengimplementasian analitik pada supply chain dapat dilakukan secara maksimal oleh sebuah perusahaan, baik itu perusahaan yang baru saja memulai mengadopsi analitik maupun perusahaan yang telah mengadopsi analitik dan ingin mengembangkannya lebih lagi, tetap membutuhkan pengukuran terhadap tingkat kematangan pengimplementasian analitik mereka [7]. SCA maturity model milik Gartner ini terdiri atas lima tingkatan dengan menggunakan tujuh dimensi. Ketujuh dimensi tersebut diantaranya yaitu goal, data, talent, organizational model, use cases, analytics techniques, serta supporting technologies [7]. SCA maturity model milik Gartner ini dapat digunakan untuk mengukur kematangan analitik yang digunakan serta untuk mengarahkan perusahaan dalam membangun kompetensi analitik mulai dari awal hingga akhir. Model maturity ini digambarkan pada Gambar 2.2. Kelima level dalam framework milik Gartner ini dapat mengubah tujuan perusahaan dari yang awalnya berfokus pada kinerja fungsional, sekarang bergeser menjadi menciptakan nilai dalam suatu jaringan supply chain. Jeff Bodenstab (2017) menjelaskan kelima level pada SCA maturity model milik Gartner sebagai berikut[20] antara lain (1) Level 1 : Pada level ini setiap kemampuan analitik terbatas hanya berfokus pada mendukung bisnis dengan tujuan fungsional. Kegiatan analitik tidak memiliki fokus bersama yang terpadu untuk mendukung kinerja supply chain. Tujuan utama pada level ini adalah penggunaan data untuk mengukur single metric di dalam fungsi tertentu, dengan ciri-ciri penggunaan excel spreadsheets masih mendominasi dan hanya menyediakan analitik yang terbatas; (2) Level 2 : Pada level ini bertujuan untuk mengukur kinerja dan juga menyediakan data untuk membuat keputusan dalam suatu fungsi di supply chain. Ciri-ciri perusahaan pada tingkatan ini adalah perusahaan membawakan data dari sistem ERP dan sistem lainnya, organisasi menjalankan tugas fungsionalnya hanya dengan kolaborasi atau sharing knowledge yang terbatas, serta target pengimplementasian perbaikan dilakukan dengan dukungan teknologi dari Excel spreadsheets, laporan-laporan, dan dashboard; (3)Level 3 : Pada level ini bertujuan meningkatkan pengambilan keputusan di seluruh internal supply chain. Perusahaan berfokus pada harmonisasi data dan tata kelola data yang baik sehingga analitik ini dapat memanfaatkan proses data secara end-to-end. Data supply chain ini nantinya akan diselaraskan dengan beberapa area seperti area pengembangan produk, penjualan, dan juga keuangan. Ciri-ciri pada level ini yaitu fokus dalam menciptakan transparansi serta mengukur kinerja proses yang ada pada seluruh bagian dalam supply chain. Analitik tingkat lanjut ini menekankan pada prediksi skenarioskenario yang akan terjadi dan menentukan langkah-langkah yang akan diambil pada supply chain secara keseluruhan; (4) Level 4 : Level ini bertujuan untuk meningkatkan kinerja supply chain dengan mitra dagang (trading partners) yang lebih luas. Pada level ini, data berasal dari sumber internal maupun eksternal dari mitra dagang untuk memfokuskan analitik pada tingkat jaringan. Teknologi yang digunakan fokus pada kemampuan multi-entreprise untuk menciptakan transparansi dan mengukur kinerja supply chain yang lebih luas tersebut. Ciri-ciri level ini yaitu analitik menjadi lebih cepat dan dinamis serta memanfatkan data milik mitra dagang seperti contohnya yaitu pabrik CPG membuat peramalan untuk peluncuran produk baru mereka dan menyesuaikannya dengan rencana tambahan berdasarkan data dari mitra; (5)Level 5 : Pada level ini, tujuan perusahaan berubah menjadi mengukur dan meningkatkan kinerja dengan jaringan mitra dagang untuk memuaskan permintaan dari pelanggan namun tetap mempertahankan margin. Data pada level ini berasal dari publik dan sumber yang tidak terstrukur, serta didapatkan juga dari Internet of Things (IoT). Ciri-ciri pada level ini yaitu pengaplikasiannya berfokus terhadap transparansi, meningkatkankan kinerja, dan menciptakan nilai pada jaringan secara keseluruhan dengan dukungan teknologi pengambilan keputusan dan eksekusi secara otomatis, yang mempertimbangkan faktor trade-off yang kompleks dan tujuan bisnis secara keseluruhan diantara para mitra. Selain kedua framework tersebut, Alberta (2017) juga mengemukakan bahwa dalam mentransformasi kemampuan data perusahaan, perlu difokuskan pada tiga pilar utama yaitu Process, People, dan Technology [21].seperti yang tertera pada Gambar 7.

Process yang dimaksudkan dalam framework ini yaitu proses bisnis yang dijalankan oleh perusahaan. Kemudian, pada pilar people merupakan bagaimana perusahaan membangun kemampuan sumber daya yang ada terkait dengan analisis data atau metode analitik. Selain melihat dari aspek proses bisnis dan juga sumber daya manusia perusahaan, framework ini juga melihat aspek teknologi atau tata kelola teknologi informasi yang dimiliki perusahaan.

Selanjutnya yaitu supply chain analytics maturity model yang dirumuskan oleh Arunachalam et al (2017). Dalam merumuskan dimensi dimensi dari big data analytics, Arunachalam menyatakan bahwa big data analytics ini merupakan suatu kemampuan sebuah organisasi untuk mengumpulkan dan mengelola data supply chain mulai dari data heterogen hingga data yang telah terorganisir [22]. Oleh karena itu, maturity model yang dibangun pada penelitian ini memiliki lima dimensi dengan tingkat kematangan (maturity level) yang berbeda-beda pada setiap dimensinya. Kelima dimensi tersebut diantaranya yatu data generation capability, data integration and management capabilities, advanced analytics capabilities, data visualization capabilities, dan data-driven culture (Tabel 3) [22].

\section{KESIMPULAN/RINGKASAN}

Mengingat pentingnya penerapan SCA dalam sebuah perusahaan, membuat perusahaan harus memahami kondisi 
tingkat kematangan dalam menerapkan SCA. Berdasarkan dari hasil tinjauan pustaka, didapatkan bahwa dalam mengukur penerapan SCA perlu melihat dari segala aspek, mulai dari segi implementasi SCA pada proses dalam supply chain dengan menggunakan model SCOR, kemudian dari segi kemampuan sumber daya manusia yang dimiliki perusahaan dalam menerapkan analitik, dan juga dari segi kematangan tata kelola TI perusahaan. Sehingga, dari ketiga aspek utama tersebut dapat dijadikan sebagai acuan dimensi SCA. Dimensi SCA tersebut nantinya akan digunakan dalam merumuskan SCA maturity model, dengan kriteria tingkat kematangan pada setiap dimensi dapat mengadopsi referensi maturity model yang ada.

\section{DAFTAR PUSTAKA}

[1] T. M. L. and N. Gillis, "Collaborating for a More Sustainable Supply Chain," Supply Chain Manag., pp. 43-49, 2012.

[2] H. H. and G. P. L. Gadde, Supply Network Strategies. Chichester: IMP Group/Wiley, 2010.

[3] N. R. Sanders, "How to use big data to drive your supply chain," Calif. Manage. Rev., vol. 58, no. 3, pp. 26-48, Mar. 2016.

[4] B. K. Chae, D. Olson, and C. Sheu, "The Impact of Supply Chain Analytics on Operational Performance: a Resource-Based View," Int. J. Prod. Res., vol. 52, no. 16, pp. 4695-4710, 2014.

[5] G. E. Smith, K. J. Watson, W. H. Baker, and J. A. Pokorski, "A Critical Balance: Collaboration and Security in the IT-Enabled Supply Chain," Int. J. Prod. Res., vol. 45, no. 11, pp. 25952613, Jun. 2007.

[6] C. S. and Z. Z. J. Mentzer, W. DeWitt, J. Keebler, S. Min, N. Nix, "Defining Supply Chain Management," J. Bus. Logist., pp. 1-25, 2001.

[7] N. Tohamy, "Use Gartner's Five-Stage Maturity Model to Reach Supply Chain Analytics Excellence," Reach Supply, 2017. .

[8] E. Triandini, A. Djunaidy, and D. Siahaan, "A maturity model for e-commerce adoption by small and medium enterprises in Indonesia," J. Electron. Commer. Organ., vol. 15, no. 1, 2017.

[9] E. Triandini, A. Djunaidy, and D. Siahaan, "Development of a conceptual model of E-commerce adoption for SMEs in Indonesia," in Information Technology and Electrical Engineering (ICITEE), 2013, pp. 93-96.

[10] R. D. Briner, Systematic Review and Evidence Synthesis as a Practice and Scholarship Tool. The Oxford Handbook of Evidence-Based Management, 2012.

[11] I. N. P. and M. Er, Supply Chain Management, 3rd ed. Surabaya: ANDI, 2017.

[12] S. C. and P. Meindl, Supply Chain Management Strategy, Planning, and Operation, 6th ed. Pearson, 2015.

[13] S. Chopra and P. Meindl, Supply Chain Management Strategy, Planning, And Operation, 5th ed. Prentice Hal, Inc, 2013.

[14] T. H. D. and J. G. Harris, Competing on Analytics: The New Science of Winning. Harvard Business School, 2007.

[15] D. G. S. and C. M. S. M. J. Schniederjans, Business Analytics Principles, Concepts, and Applications. New Jersey: Pearson Education, 2014.

[16] J. O. and R. R, "The Promise of Advanced Supply Chain Analytics," Supply Chain Management Review, 2011.

[17] K. C. Laudon and J. P. Laudon, Essentials of Management Information Systems, 8th ed. New Jersey: son Education, 2009.

[18] E. N. and T. P. G. Wang, A. Gunasekaran, "Bid Data Analytics in Logistics and Supply Chain Management: Certain Investigations for Reasearch and Applications," Int. J. Prod. Econ., pp. 98-110.

[19] E. V. and R. Scapens, "The governance of Inter-Organisational Relationships During Different Supply Chain Maturity Phases," Ind. Mark Manag, pp. 68-82, 2015.

[20] "Accenture, "Accenture Global Operations Megatrends Study," 2014. .

[21] Alberta, Enterprise Data Analytics Strategic Plan: Transforming Government Data Capability. Edmonton: GoA Enterprise Data Analytics Strategic Plan, 2017.

[22] D. e. a. Arunachalam, "Understanding Big Data Analytics Capabilities in Supply chain Management: Unravelling the
Issues, Challenges and Implications for Practice," Transp. Res. Part E, pp. 1-21, 2017. 